\title{
CD4saurus Rex \&HIVelociraptor vs. development of clinically useful immunological markers: a Jurassic tale of frozen evolution
}

\author{
Andrea De Maria ${ }^{1,2,3^{*}}$ and Andrea Cossarizza ${ }^{4,5}$
}

\begin{abstract}
One of the most neglected areas of everyday clinical practice for HIV physicians is unexpectedly represented by CD4 T cell counts when used as an aid to clinical decisions. All who care for HIV patients believe that CD4+ T cell counts are a reliable method to evaluate a patient immune status. There is however a fatalistic acceptance that besides its general usefulness, CD4+ T cell counts have relevant clincal and immunological limits. Shortcomings of CD4 counts appear in certain clinical scenarios including identification of immunological nonresponders, subsequent development of cancer on antiretroviral teatment, failure on tretment simplification. Historical and recently described parameters might be better suited to advise management of patients at certain times during their disease history. Immunogenotypic parameters and innate immune parameters that define progression as well as immune parameters associated with immune recovery are available and have not been introduced into validation processes in larger trials. The scientific and clinical community needs an effort in stimulating clinical evolution of immunological tests beyond "CD4saurus Rex" introducing new parameters in the clinical arena after appropriate validation
\end{abstract}

Keywords: $C D 4+T$ cells, immune reconstitution, antiviral treatment, clinical trials

\section{Introduction}

Basic biomedical research is crucial for understanding pathogenetic mechanisms of diseases, as well as to develop new techniques drugs or concepts aimed at improving patient clinical care. Clinical implications of basic research are regularly reported in major journals in an effort to improve the transfer of benchwork into bedside clinical practices[1], and whenever promising steps in basic research fail to be introduced, this is underscored [2].

After the identification of CD4+ T cells as the main target HIV replication, scientists focused on several important issues, including pathogenesis of mucosal infection[3-8], clearance of residual replication[9-13], evaluation of the involvement of innate immunity in disease progression[14-16], and identification of immunological correlates of protection for vaccine studies[17-20].

\footnotetext{
* Correspondence: de-maria@unige.it

'Centro di Eccellenza per la Ricerca Biomedica, Università di Genova, Genova, Italy

Full list of author information is available at the end of the article
}

New cell subsets, receptors, cytokines, and signaling pathways were described [16,21-25], and widely available techniques for the ex vivo study of cells of the innate immune system (e.g. pDC, mDC, NK cells, NKTcells) or of Toll-like receptors were introduced. Models of HIV pathogenesis have been upgraded to account for and adjust to the new players and their functional characteristics. By "CD4" we now define at least 5 different CD4+ $\mathrm{T}$-cell lineages, central and peripheral memory cells with variable effector functions (Figure 1). Evolution of our understanding of CD4+ T-cell type and function had however little impact on the Jurassik Park of clinical HIV care and antiretroviral trials. In the majority of cases, indeed, "immunology" is still represented by "quantitative determination of CD4+ T-cell numbers" alone to assess the immune status of routine patients attending HIV clinics.

\section{CD4saurus Rex: a relic from old times}

For some reason, apparently unexplained factors prevented our clinical practice from evolving moving

\section{Ciomed Central}




\section{What are CD4+ T cells?}

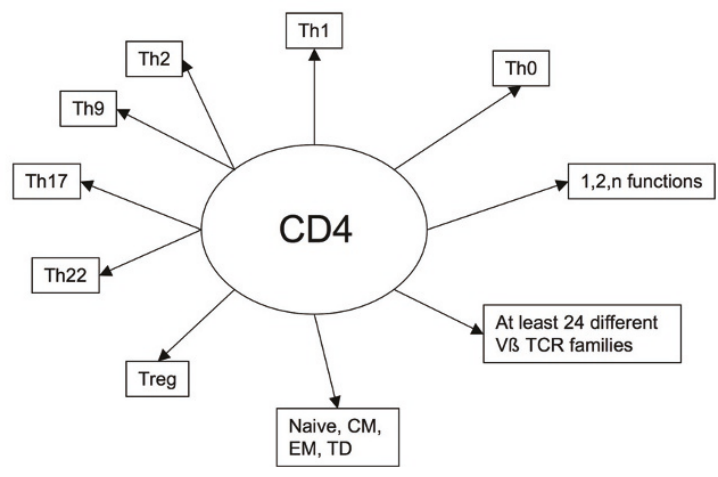

Figure 1 Possible definitions of CD4+ T-cells based on current knowledge. CD4+ cell counts only represent sums of individual subsets and do not reflect actual composition. Patients with equal CD4+ cell counts may reflect different proportional composition with possibly widely diverging functional immune characteristics.

from discussing patients in terms of CD4+ T-cell counts alone to including additional specific tests. Clinical activity and knowledge has evolved rapidly in the same field leading to inclusion in everyday clinical life of DExa, PK/PD, ultrasensitive viral load, phenotypic and genotypic resistance evaluation. When it however comes to immunology, clinicians stick to a very successful but Jurassic test like CD4+ T-cell counts, which for the moment we could nickname "CD4saurus Rex". Unlike real Dinosaurs, CD4+ cell count and its clinical use has neither evolved/upgraded nor vanished each time a clinician is assessing a patient immune status before taking critical decisions with HIV patients.

There are few doubts that absolute CD $4+\mathrm{T}$ cell counts have served, and still serve, as a very robust surrogate for progression to AIDS or death. They correlate generally well to the level of immune competence of patients with[26,27] or without[28] HIV infection, and also in children [29].

Proof of the robustness of this relic of immunological evolution is represented by its extensive use as a surrogate marker of immune competence to stratify or select patients in all recent trials evaluating or licensing the use of newer drug classes or ART regimens and in studies assessing the optimal time for ART initiation.

Even in the quest to identify additional risk factors for HIV-associated non-AIDS defining diseases, including nephropathy of cardiovascular disease, CD4+ T cell counts are the only immune parameter used to stratify patient cohorts[30,31].

\section{Shortcomings of CD4saurus Rex}

The concept of CD4+ counts as clinical surrogate markers is still valid today and should continue to be used in routine patient follow-up. However, there are areas of clinical experience where it falls short of our needs.

Opportunistic infections may be sometimes observed in patients presenting with CD4 $+\mathrm{T}$ cell counts well above the critical range usually referred to for a given infection, as is the case for PML, TB[32-34], lymphoma [35] or Kaposi sarcoma patients who may unexpectedly present with relatively high CD4+ T cell numbers in the $300-400 / \mu \mathrm{l}$ range[36]. Conversely, at any given CD4+ cell count stratum, a fraction of patients have chances to develop PML, TB, lymphoma or KS, but CD4+ cell counts alone do not help us to further narrow down our attention on those who will actually develop disease. A surprisingly sustained incidence of HPV-associated pathology (e.g., cervical carcinoma, anal carcinoma) is observed even after successful ART with rising CD4+ cell counts[37,38]. Drug simplification to lopinavir/ritonavir monotherapy is effective at 96 weeks, but only in a subset of patients (47\%) not identified by CD4 +standards at baseline.[39].

These events are apparently unexplained to the clinician each time they are observed and are usually accepted as one would accept a rainy day. Other factors in the immune playground are likely to be involved, but "CD4saururs Rex" still grabs center stage, and we are missing part of the picture.

Treatment interruptions guided by the number of CD4+ T cells (CD4+GTI) have been lately discouraged by studies that showed significant risk of disease progression to AIDS or death or of cardiovascular events in patients selected on a narrow and low range of CD4+ T cells (i.e.350-200 CD4+/ $\mu \mathrm{l}$ ) [40]. Other studies however show that CD4+GTI is feasible and bears negligible/no risks for patients with different characteristics and considerably higher CD4+ cell counts $(500-750 / \mu \mathrm{l})[41,42]$. Analysis of progressing patients on CD4+GTI shows that other phenotypic or functional immune variables beyond CD4+ cell counts (e.g.CD4+ nadir, NK cell phenotype[43]) may define the subset of patients for whom STI of CD4+GTI could be an option.

A similar issue is represented by immunological discordance on ART, which is observed in about 15-20\% of drug-naïve patients starting ART[44]. Patients and physicians may develop anxiety over failure to recover CD4+ cells, over prophylaxis and over the risk of developing AIDS.

Thus, at the single patient level, which means our everyday life, we have to cope with an absolute number, without any other parameter that could help explain outliers, aid individualized management optimization or help to predict - or at least express a likelihood 
-whether a given patient will or will not develop an unwanted condition/disease course.

\section{What failed on the path of CD4+saurus Rex evolution,} and which options are available

The reasons underlying this "frozen evolution" of immunological tests applied to HIV patients are multifaceted. Besides the outstanding robustness in terms of wide availability, standardization, and quality control of "CD4saurus Rex", there are few additional assays that raise some interest and that have been proposed as an additional qualitative or quantitative measure of the likelihood for a patient to develop a specific pattern of progression or of response to a given treatment.

The drive to improve basic understanding of HIV associated immune derangements could play a role in leaving little time and money to refine clinical use of acquired experience. Competition and a limited propensity of different researchers to integrate techniques developed elsewhere into clinical practice, also may play a role in the lack of translation of benchwork into bedside assets for patients. The misleading perception that budget restraints in immune evaluations are justified, particularly in the absence of wide integration of immunology centers, leaves us with large studies where CD4+ $\mathrm{T}$-cells are the only immune measure, preventing inclusion of additional tests (Figure 2).

Alternative use of qualitative CD4+ T cell analysis, instead of CD4+ T cell count alone, has been proposed for other infectious diseases. It is well known that changes in the phenotype of CD4+ T cells occur in a large number of viral infections, and can be easily monitored. For example, atypical lymphocytes expressing $\mathrm{CD} 4+/ \mathrm{CD} 45 \mathrm{RO}+$ may play the role of helper $\mathrm{T}$ cells in the development of the mononucleosis-like syndrome which is associated with Hepatitis-A infection[45].
During Epstein-Barr infection, a high number of CD4 +Foxp3+ Treg cells can be localized in tonsils, which are the port of entry of the virus [46], and their role in inhibiting CD8+ $\mathrm{T}$ cell activity is under investigation. Recently, flow cytometry has also revealed its utility in providing informative patterns that can differentiate between infections of bacterial and viral origin. Indeed, these patterns have been obtained by combining the fractions of HLA-DR expressing T cell subpopulations with the level of CD40 on monocytes [47].

\section{Discussion}

An improved approach to clinical development of immune measures should be designed and validated in the HIV arena. Embedding promising - or rather confirmed -immune parameters in new phase III/IV trials for ART or management optimization would provide a stimulus for the validation of additional clinical tools (Table 1). So far, no large study has tried to validate any of known potential markers which would add clinical information to CD4+ T-cell counts. These tests, including expression of CD38 or CD127, degree of $\mathrm{T}$ or NK cell activation (e.g.:HLA-DR, CD69 or Ki67), NCR expression by NK cells, or KIR:HLAtyping, could be used to flag different clinical options or outcomes at different times of the disease/treatment course (e.g.: immune-reconstitution, ART switch to monotherapy in selected patients or CD4+GTI, surveillance for unexpected opportunistic events including AIDS defining and non-AIDS defining neoplasms).

In industrialized countries, most laboratories are equipped with flow cytometers that are able to analyze routinely multiple (at least 4 , up to 8 ) fluorescent cellular markers. More sophisticated approaches based on polychromatic flow cytometry have allowed to identify a relevant heterogeneity within the $\mathrm{CD} 4+\mathrm{T}$ cell

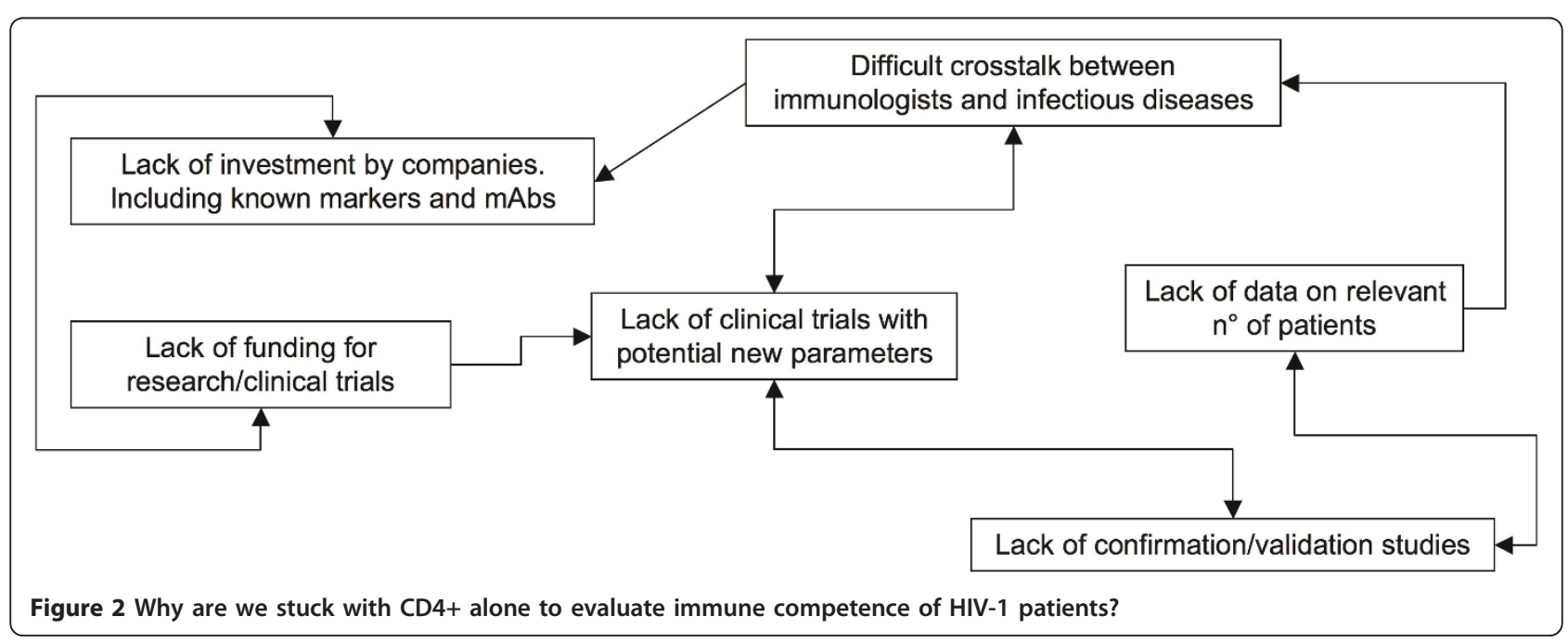


Table 1 List of useful or promising analyses, in addition to CD4+saurus Rex testing, so far unaccounted for in clinical trial validation but potentially relevant in every-day patient management and clinical decisions

\begin{tabular}{|c|c|c|c|}
\hline What to test & Who and When & Possible use/interpretation & Ref. \\
\hline $\begin{array}{l}\text { PBMC } \\
\text { PD1 }^{+} \mathrm{DR}^{+} \mathrm{Ki}^{+} 7^{+} \mathrm{CD}^{+} \\
\mathrm{Ki}^{+} 7^{+} \mathrm{PD}-1^{+} \mathrm{CD} 4^{+\mathrm{Treg}} \\
\text { Th17 cytokine profile }\end{array}$ & $\begin{array}{l}\text { Before CART in adv.naive and AIDS- } \\
\text { presenter pts }\end{array}$ & $\begin{array}{l}\text { Increase. Predict likelihood of IRIS. Diagnosis of IRIS (uppon } \\
\text { symptoms }\end{array}$ & [59] \\
\hline $\begin{array}{l}\text { Plasma TNF-a, IL-4, IL- } \\
\text { 17, VEGF, } \\
\text { G-CSF, GM-CSF, CCL2 } \\
\text { (MCP-1) }\end{array}$ & pt.with cryptococcal meningitis & Increase. Predicts high risk of IRIS & {$[60]$} \\
\hline $\begin{array}{l}\text { PBMC } \\
\text { CD56bright NK cells } \\
\text { NKp30+CD56+, NKp46 } \\
+ \text { CD56+ } \\
\text { NK cells }\end{array}$ & $\begin{array}{l}\text { Before Voluntary or CD4+guided } \\
\text { Treatment interruption }\end{array}$ & $\begin{array}{l}\text { Increase. Advise against interruption for risk of rapid CD4 decrease } \\
\text { when markers are increased }\end{array}$ & [43] \\
\hline $\begin{array}{l}\text { PBMC } \\
\text { CD4+/62L+/RA+ } \\
\text { CD8+/CD38+/DR+ } \\
\text { CD8+/62L+/RA+ }\end{array}$ & Wk16-24 of cART - Adolescents & Increase. Risk of Virological Failure after initial response & [61] \\
\hline $\begin{array}{l}\text { PBMC } \\
\text { HLA-Bw4 (incl.HLA-B*57, } \\
\text { HLA-B*27) }\end{array}$ & HIV infection, At first diagnosis & $\begin{array}{l}\text { Presence. Defines lower risk of progression, chances of Elite } \\
\text { Controlling, slow progression, lower VL }\end{array}$ & {$[62-65]$} \\
\hline $\begin{array}{l}\text { PBMC } \\
\text { HLA-B*57 + KIR3DS1 }\end{array}$ & Exposed uninfected partners, Any time & Presence. Decreased risk of infection upon HIV exposure & {$[66-68]$} \\
\hline $\begin{array}{l}\text { PBMC } \\
\text { HLA-B*57 + } \\
\text { KIR3DL1high }\end{array}$ & Exposed uninfected partners, Any time & Presence. Decreased risk of infection upon HIV exposure & [69] \\
\hline HLA-B*57 & HIV-Infected, Before cART start & Presence. Defines adverse reaction to Abacavir & [70] \\
\hline \multirow[t]{2}{*}{ CCR5-み2, CCR2-64I } & At diagnosis. & Presence. Slower disease progression, lower VL & [71] \\
\hline & Before cART & Less time to undetectable $\mathrm{VL}$, decreased risk of AIDS & {$[72,73]$} \\
\hline
\end{tabular}

compartment [48]. Additional information on the immunological status of a given patient can be easily obtained, and should be customized on patient needs. Testing would not be required on a regular "routine" basis, but rather could be applied just before a "strategic management decision", to estimate the likelihood of a given patient or patient group to have different clinical outcomes. This would contain costs and provide optimal use of a dedicated test. For example, concerning management of a drug naïve patient, one of the main questions would be whether the patient will become an immunological non-responder. Thus, tests for assessing the capacity of producing new T-cells, in terms of thymic functionality (such as the amount of TREC+cells, IL-7 plasma levels, expression of CD127) [49-51] could be introduced. Similarly, KIR:HLA carriage and IL-28 Bpolymorphisms condition significantly treatment response during $\mathrm{HCV}$ infection[52-54] and has implications also on disease course in coinfected patients and possibly bear on response to ART[55-58]. Concerning an advanced patient failing a drug regimen, markers of $\mathrm{CD} 8+\mathrm{T}$ cell activation (such as CD38, CD95 or MHC class II), differentiation (CD45RA, CCR7 or CD62L), survival (CD127) and of
CD4 activation and differentiation could be crucial (Table 1). Similar considerations could be applied to successfully treated patients with suppressed VL and recovered CD4+ T cell count, who would candidate for simplification regimens (or for possible drug vacation on the basis of NK activating/inhibitory receptor phenotype[43] (Table 1). Last but not least, age-related immunological changes in a huge number of parameters, including the subpopulations of CD4+ T cells, have to be considered when "normal" levels of a biomarker are studied, considering that the aging of HIV+ patients is an emerging problem of relevant importance (50).

\section{Conclusion}

In conclusion, time has come to introduce complementary customized parameters, in addition to CD4+ cell counts, in the clinical care of HIV-infected patients in order to provide additional immuno-virological stratification criteria. This may be achieved by specifically investing on appropriate validation/standardization strategies in clinical trials (extending in range from ART initiation to ART optimization) using available parameters 


\section{Acknowledgements}

This work has been supported in part by grants awarded by Istituto Superiore di Sanita (I.S.S., Programma Nazionale AIDS n. 40G.41/40F.55 and 45G.11), Accordi di Collaborazione Scientifica n. 40D61, 40H69 and 45D/1.13

\section{Author details}

'Centro di Eccellenza per la Ricerca Biomedica, Università di Genova, Genova, Italy. ${ }^{2}$ Dipartimento Scienze della Salute (DISSAL), Università di Genova, Italy. ${ }^{3}$ S.S. Infettivologia, Istituto Nazionale per la ricerca sul Cancro, Genova, Italy. ${ }^{4}$ Dipartimento di Scienze Biomediche, Università di Modena e Reggio Emilia, Modena, Italy. ${ }^{5}$ Departamento de Bioquímica y Biología Molecular, Universidad de Valencia, Valencia, Spain.

\section{Authors' contributions}

ADM conceived the design of the commentary, discussed and wrote the manuscript. AC participated in the design of the commentary, discussed and wrote the manuscript. All authors read and approved the final manuscript

\section{Competing interests}

The authors declare that they have no competing interests.

Received: 19 April 2011 Accepted: 16 June 2011

Published: 16 June 2011

\section{References}

1. Guatelli J: How Innate Immunity Can Inhibit the Release of HIV-1 from Infected Cells. New England Journal of Medicine 362:553-554.

2. Van Hemelen D, Van Oosterhout AJM: Adjuvants for immunotherapy: lost in translation? Clinical \& Experimental Allergy 2009, 39:1783-1785.

3. Ahlers JD, Belyakov IM: Strategies for optimizing targeting and delivery of mucosal HIV vaccines. European Journal of Immunology 2009, 39:2657-2669.

4. Cunningham AL, Carbone F, Geijtenbeek TBH: Langerhans cells and viral immunity. European Journal of Immunology 2008, 38:2377-2385

5. Piacentini L, Fenizia C, Naddeo V, Clerici M: Not just sheer luck! Immune correlates of protection against HIV-1 infection. Vaccine 2008, 26:3002-3007.

6. Neutra MR, Kozlowski PA: Mucosal vaccines: the promise and the challenge. Nat Rev Immunol 2006, 6:148-158.

7. Zinkernagel RM: On Immunity Against Infections and Vaccines: Credo 2004. Scandinavian Journal of Immunology 2004, 60:9-13.

8. Liu L, Zhong Q, Tian T, Dubin K, Athale SK, Kupper TS: Epidermal injury and infection during poxvirus immunization is crucial for the generation of highly protective T cell-mediated immunity. Nat Med 2010, 16:224-227.

9. Nottet $H$, van Dijk S, Fanoy E, Goedegebuure I, de Jong D, Vrisekoop N, van Baarle D, Boltz V, Palmer S, Borleffs J, Boucher C: HIV-1 can persist in aged memory CD4+ T lymphocytes with minimal signs of evolution after 8.3 years of effective highly active antiretroviral therapy. J Acquir Immune Defic Syndr 2009, 50:345-353.

10. Bello G, Casado C, Sandonis V, Alvaro-Cifuentes T, dos Santos CAR, Garcia S, Rodriguez C, del Romero J, Pilotto JH, Grinsztejn B, et al: Plasma Viral Load Threshold for Sustaining Intrahost HIV Type 1 Evolution. AIDS Research and Human Retroviruses 2007, 23:1242-1250.

11. Dinoso JB, Rabi SA, Blankson JN, Gama L, Mankowski JL, Siliciano RF, Zink MC, Clements JE: A Simian Immunodeficiency Virus-Infected Macaque Model To Study Viral Reservoirs That Persist during Highly Active Antiretroviral Therapy. The Journal of Virology 2009, 83:9247-9257.

12. Dinoso JB, Kim SY, Wiegand AM, Palmer SE, Gange SJ, Cranmer L, O'Shea A, Callender M, Spivak A, Brennan T, et al: Treatment intensification does not reduce residual HIV-1 viremia in patients on highly active antiretroviral therapy. Proceedings of the National Academy of Sciences 2009, 106:9403-9408.

13. Miura T, Brockman MA, Schneidewind A, Lobritz M, Pereyra F, Rathod A, Block BL, Brumme ZL, Brumme CJ, Baker B, et al: HLA-B57/B*5801 Human Immunodeficiency Virus Type 1 Elite Controllers Select for Rare Gag Variants Associated with Reduced Viral Replication Capacity and Strong Cytotoxic T-Lymphotye Recognition. J Virol 2009, 83:2743-2755.

14. Iannello A, Boulassel M-R, Samarani S, Debbeche O, Tremblay C, Toma E, Routy J-P, Ahmad A: Dynamics and Consequences of IL-21 Production in HIV-Infected Individuals: A Longitudinal and Cross-Sectional Study. J Immunol 184:114-126.
15. De Maria A, Fogli M, Costa P, Murdaca G, Puppo F, Mavilio D, Moretta A, Moretta $L$ : The impaired NK cell cytolytic function in viremic HIV-1 infection is associated with a reduced surface expression of natural cytotoxicity receptors (NKp46, NKp30 and NKp44). Eur J Immunol 2003, 33:2410-2418

16. De Maria A, Moretta L: NK cell function in HIV-1 infection. Curr HIV Res 2008, 6:433-440

17. Engram JC, Dunham RM, Makedonas G, Vanderford TH, Sumpter B, Klatt NR, Ratcliffe SJ, Garg S, Paiardini M, McQuoid M, et al: Vaccine-Induced, Simian Immunodeficiency Virus-Specific CD8+ T Cells Reduce Virus Replication but Do Not Protect from Simian Immunodeficiency Virus Disease Progression. J Immunol 2009, 183:706-717.

18. Schell J, Rose NF, Fazo N, Marx PA, Hunter M, Ramsburg E, Montefiori D, Earl P, Moss B, Rose JK: Long-term vaccine protection from AIDS and clearance of viral DNA following SHIV89.6P challenge. Vaccine 2009, 27:979-986.

19. Appay V, Douek DC, Price DA: CD8+ T cell efficacy in vaccination and disease. Nat Med 2008, 14:623-628.

20. Piacentini L, Biasin M, Fenizia C, Clerici M: Genetic correlates of protection against HIV infection: the ally within. Journal of Internal Medicine 2009, 265:110-124.

21. Torheim EA, Ndhlovu LC, Pettersen FO, Larsen T-L, Jha AR, Torgersen KM, Kvale D, Nixon DF, Taskén K, Aandahl EM: Interleukin-10-secreting T cells define a suppressive subset within the HIV-1-specific T-cell population. European Journal of Immunology 2009, 39:1280-1287.

22. Middendorp S, Nieuwenhuis EES: NKT cells in mucosal immunity. Mucosal Immunol 2009, 2:393-402.

23. Allers K, Loddenkemper C, Hofmann J, Unbehaun A, Kunkel D, Moos V, Kaup F-J, Stahl-Hennig C, Sauermann U, Epple H-J, Schneider T: Gut Mucosal FOXP3+ Regulatory CD4+ T Cells and Non-Regulatory CD4+ T Cells are Differentially Affected by SIV Infection in Rhesus Macaques. J Virol , JVI.01715-01709.

24. Torheim EA, Ndhlovu LC, Pettersen FO, Larsen T-L, Jha AR, Torgersen KM, Kvale D, Nixon DF, TaskËn K, Aandahl EM: Interleukin-10-secreting T cells define a suppressive subset within the HIV-1-specific T-cell population. European Journal of Immunology 2009, 39:1280-1287.

25. Becker C, Taube C, Bopp T, Becker C, Michel K, Kubach J, Reuter S, Dehzad N, Neurath MF, Reifenberg $K$, et al: Protection from graft-versushost disease by HIV-1 envelope protein gp120-mediated activation of human CD4+CD25+ regulatory T cells. Blood 2009, 114:1263-1269.

26. Masur H, Ognibene F, Yarchoan R, Shelhamer J, Baird B, Travis W, Suffredini A, Deyton L, Kovacs J, Falloon J, et al: CD4 counts as predictors of opportunistic pneumonias in human immunodeficiency virus (HIV) infection. Ann Intern Med 1989, 111:223-231.

27. Saah A, Muñoz A, Kuo V, Fox R, Kaslow R, Phair J, Rinaldo CJ, Detels R, Polk B: Predictors of the risk of development of acquired immunodeficiency syndrome within 24 months among gay men seropositive for human immunodeficiency virus type 1: a report from the Multicenter AIDS Cohort Study. Am J Epidemiol 1992, 135:1147-1155.

28. Smith DK, Neal JJ, Holmberg SD: Unexplained Opportunistic Infections and CD4+ T-Lymphocytopenia without HIV Infection - An Investigation of Cases in the United States. New England Journal of Medicine 1993, 328:373-379.

29. Bunders M, Cortina-Borja M, Newell M, Study EC: Age-related standards for total lymphocyte, CD4+ and CD8+ T cell counts in children born in Europe. Pediatr Infect Dis J 2005, 24:595-600.

30. Data Collection on Adverse Events of Anti HIVDSG: Changes Over Time in Risk Factors for Cardiovascular Disease and Use of Lipid-Lowering Drugs in HIV-Infected Individuals and Impact on Myocardial Infarction. Clinical Infectious Diseases 2008, 46:1101-1110.

31. Worm SW, Sabin C, Weber R, Reiss P, El-Sadr W, Dabis F, De Wit S, Law M, Monforte ADA, Friis-M $\sqrt{ } T|l| l$ r $N$, et al: Risk of Myocardial Infarction in Patients with HIV Infection Exposed to Specific Individual Antiretroviral Drugs from the 3 Major Drug Classes: The Data Collection on Adverse Events of Anti-HIV Drugs (D:A:D) Study. Journal of Infectious Diseases 201:318-330

32. Cinque P, Koralnik IJ, Gerevini S, Miro JM, Price RW: Progressive multifocal leukoencephalopathy in HIV-1 infection. The Lancet Infectious Diseases 2009, 9:625-636.

33. Crowe S, Carlin J, Stewart K, Lucas C, Hoy J: Predictive value of CD4 lymphocyte numbers for the development of opportunistic infections 
and malignancies in HIV-infected persons. J Acquir Immune Defic Syndr 1991, 4:770-776

34. Girardi E, Antonucci G, Armignacco O, Salmaso S, Ippolito G: Tuberculosis and AIDS: a retrospective, longitudinal, multicentre study of Italian AIDS patients. Italian group for the study of tuberculosis and AIDS (GISTA). J Infect 1994, 28:261-269.

35. Guech-Ongey M, Simard EP, Anderson WF, Engels EA, Bhatia K, Devesa SS, Mbulaiteye SM: AIDS-related Burkitt lymphoma in the United States: what do age and CD4 lymphocyte patterns tell us about etiology and/or biology? Blood 2010, 116:5600-5604.

36. Maurer T, Ponte M, Leslie K: HIV-Associated Kaposi's Sarcoma with a High CD4 Count and a Low Viral Load. New England Journal of Medicine 2007, 357:1352-1353.

37. D'Souza G, Wiley D, Li X, Chmiel J, Margolick J, Cranston R, Jacobson L: Incidence and epidemiology of anal cancer in the multicenter AIDS cohort study. J Acquir Immune Defic Syndr 2008, 48:491-499.

38. Dorrucci M, Suligoi B, Serraino D, Tirelli U, Rezza G, Study IH-S: Incidence of invasive cervical cancer in a cohort of HIV-seropositive women before and after the introduction of highly active antiretroviral therapy. J Acquir Immune Defic Syndr 2001, 4.

39. Ghosn J, Flandre P, Cohen-Codar I, Girard PM, Chaix ML, Raffi F, Dellamonica P, NgoVan P, Norton M, Delfraissy JF, et al: Long-term (96week) follow-up of antiretroviral-naïve HIV-infected patients treated with first-line lopinavir/ritonavir monotherapy in the MONARK trial*. HIV Medicine 11:137-142.

40. The Strategies for Management of Antiretroviral Therapy Study G: Major Clinical Outcomes in Antiretroviral Therapy (ART),ÄiNaive Participants and in Those Not Receiving ART at Baseline in the SMART Study. Journal of Infectious Diseases 2008, 197:1133-1144.

41. Maggiolo F, Airoldi M, Callegaro A, Martinelli C, Dolara A, Bini T, Gregis G, Quinzan G, Ripamonti D, Ravasio V, Suter F: CD4 cell-guided scheduled treatment interruptions in HIV-infected patients with sustained immunologic response to HAART. AIDS 2009, 27:799-807, 710.1097/ QAD.1090b1013e328321b328375e.

42. Mussini C, Bedini A, Borghi V, Guaraldi G, Esposito R, Barchi E, Enilia R, Cozzi-Lepri A, Philips A, Ortolani P, et al: CD4 cell-monitored treatment interruption in patients with a CD4 cell count $>500 \times 106$ cells/l. AIDS 2005, 19:287-294.

43. Bozzano F, Nasi M, Bertoncelli L, Nemes E, Prati F, Marras F, Mussini C, Moretta L, Cossarizza A, De Maria A: NK-cell phenotype at interruption underlies widely divergent duration of CD4+-guided antiretroviral treatment interruption. International Immunology 23:109-118.

44. Zoufaly $A$, an der Heiden M, Kollan C, Bogner JR, F $\sqrt{ }$ §tkenheuer $G$, Wasmuth JC, Stoll M, Hamouda O, van Lunzen J, the ClinSurv Study G: Clinical Outcome of HIV-Infected Patients with Discordant Virological and Immunological Response to Antiretroviral Therapy. Journal of Infectious Diseases 203:364-371.

45. Watanabe $H$, Sekine $H$, Uruma T, Nagasaki S, Tsunoda T, Machida Y, Kobayashi $\mathrm{K}$, Igarashi $\mathrm{H}$ : Increase of atypical lymphocytes expressing CD4 +/CD45RO+ in an infectious mononucleosis-like syndrome associated with hepatitis A virus infection. Journal of Infection and Chemotherapy 2009, 15:187-190.

46. Chow Y-H, Chang H-W, Sia R, Chong P, Sia C: Tonsillar CD4\&lt;sup\&gt; +\&lt;/sup\&gt;FOXP3\&lt;sup\&gt;+\&lt;/sup\&gt; T-regulatory cell dynamics in primary EBV infection. Immunologic Research 50:97-101.

47. Janols H, Bredberg A, Thuvesson I, Janciauskiene S, Grip O, Wullt M: Lymphocyte and monocyte flow cytometry immunophenotyping as a diagnostic tool in uncharacteristic inflammatory disorders. BMC Infectious Diseases 10:205.

48. Lugli E, Pinti M, Nasi M, Troiano L, Ferraresi R, Mussi C, Salvioli G, Patsekin V, Robinson JP, Durante C, et al: Subject classification obtained by cluster analysis and principal component analysis applied to flow cytometric data. Cytometry Part A 2007, 71A:334-344.

49. Bai F, Bellistrì G, Tincati C, Savoldi A, Pandolfo A, Bini T, Carpani G, Sinigaglia E, Marchetti G, dAM A: Reduced CD127 expression on peripheral CD4+ T cells impairs immunological recovery in course of suppressive highly active antiretroviral therapy. AIDS 2010, 24:2590-2593.

50. Bellistri GM, Casabianca A, Merlini E, Orlandi C, Ferrario G, Meroni L, Galli M, Magnani M, Monforte AdA, Marchetti G: Increased Bone Marrow Interleukin-7 (IL-7)/IL-7R Levels but Reduced IL-7 Responsiveness in HIV-
Positive Patients Lacking CD4+ Gain on Antiviral Therapy. PLOS ONE 5: e15663.

51. Marziali M, De Santis W, Carello R, Leti W, Esposito A, Isgrò A, Fimiani C, Sirianni M, Mezzaroma I, Aiuti F: T-cell homeostasis alteration in HIV-1 infected subjects with low CD4 T-cell count despite undetectable virus load during HAART. AIDS 2006, 20:2033-2041.

52. Vidal-Castineira JR, Lopez-Vazquez A, Diaz-Pena R, Alonso-Arias R, MartinezBorra J, Perez R, Fernandez-Suarez J, Melon S, Prieto J, Rodrigo L, LopezLarrea C: Effect of Killer Immunoglobulin-Like Receptors in the Response to Combined Treatment in Patients with Chronic Hepatitis C Virus Infection. J Virol 2010, 84:475-481.

53. Thompson AJ, Muir AJ, Sulkowski MS, Ge D, Fellay J, Shianna KV, Urban T, Afdhal NH, Jacobson IM, Esteban R, et al: Interleukin-28B Polymorphism Improves Viral Kinetics and Is the Strongest Pretreatment Predictor of Sustained Virologic Response in Genotype 1 Hepatitis C Virus. Gastroenterology 2010, 139:120-129, e118.

54. Mangia A, Thompson AJ, Santoro R, Piazzolla V, Tillmann HL, Patel K, Shianna KV, Mottola L, Petruzzellis D, Bacca D, et al: An IL28B Polymorphism Determines Treatment Response of Hepatitis C Virus Genotype 2 or 3 Patients Who Do Not Achieve a Rapid Virologic Response. Gastroenterology 2010, 139:821-827, e821.

55. Long BR, Ndhlovu LC, Oksenberg JR, Lanier LL, Hecht FM, Nixon DF, Barbour JD: KIR3DS1 Conferral of Enhanced Natural Killer Cell Function in Early HIV-1 Infection. J Virol 2008, JVI.02449-02407.

56. Wong AHW, Williams K, Reddy S, Wilson D, Giddy J, Alter G, Ghebremichael M, Carrington M, Ndung'u T, Walker BD, et al: Alterations in Natural Killer Cell Receptor Profiles During HIV Type 1 Disease Progression Among Chronically Infected South African Adults. AIDS RESEARCH AND HUMAN RETROVIRUSES 2010, 26:459-469.

57. Fogli M, Costa P, Murdaca G, Setti M, Mingari MC, Moretta L, Moretta A, De Maria A: Significant NK cell activation associated with decreased cytolytic function in peripheral blood of HIV-1-infected patients. Eur J Immunol 2004, 34:2313-2321.

58. Clausen LN, Weis N, Astvad K, Schønning K, Fenger M, Krarup H, Bukh J, Benfield T: Interleukin-28B polymorphisms are associated with hepatitis $C$ virus clearance and viral load in a HIV-1-infected cohort. Journal of Viral Hepatitis 2011, 18:e66-e74.

59. Antonelli LRV, Mahnke Y, Hodge JN, Porter BO, Barber DL, DerSimonian R, Greenwald JH, Roby G, Mican J, Sher A, et al: Elevated frequencies of highly activated CD4+ T cells in HIV+ patients developing immune reconstitution inflammatory syndrome. Blood 2010, 116:3818-3827.

60. Boulware DR, Meya DB, Bergemann TL, Wiesner DL, Rhein J, Musubire A, Lee SJ, Kambugu A, Janoff EN, Bohjanen PR: Clinical Features and Serum Biomarkers in HIV Immune Reconstitution Inflammatory Syndrome after Cryptococcal Meningitis: A Prospective Cohort Study. PLoS Med 2010, 7: e1000384.

61. Rudy BJ, Lindsey JC, Flynn PM, Bosch RJ, Wilson CM, Hughes ME, Douglas SD: Immune Reconstitution and Predictors of Virologic Failure in Adolescents Infected through Risk Behaviors and Initiating HAART: Week 60 Results from the PACTG 381 Cohort. AIDS Research and Human Retroviruses 2006, 22:213-221.

62. Goulder PJ BM, Krausa P, Mclntyre K, Crowley S, Morgan B, Edwards A Giangrande P, Phillips RE, McMichael AJ: Novel, cross-restricted, conserved, and immunodominant cytotoxic T lymphocyte epitopes in slow progressors in HIV type 1 infection. AIDS Res Hum Retroviruses 1996, 12:1691-1698.

63. Kaslow RA CM, Apple R, Park L, Muñoz A, Saah AJ, Goedert JJ, Winkler C, O'Brien SJ, Rinaldo C, Detels R, Blattner W, Phair J, Erlich H, Mann DL: Influence of combinations of human major histocompatibility complex genes on the course of HIV-1 infection. Nat Med 1996, 2:405-411.

64. Flores-Villanueva PO, Yunis EJ, Delgado JC, Vittinghoff E, Buchbinder S, Leung JY, Uglialoro AM, Clavijo OP, Rosenberg ES, Kalams SA, et al: Control of HIV-1 viremia and protection from AIDS are associated with HLA-Bw4 homozygosity. Proceedings of the National Academy of Sciences 2001, 98:5140-5145.

65. Costello C, Tang J, Rivers C, Karita E, Meizen-Derr J, Allen S, Kaslow RA: HLAB*5703 independently associated with slower HIV-1 disease progression in Rwandan women. AIDS 1999, 13:1990.

66. Boulet S, Sharafi S, Simic N, Bruneau J, Routy J-P, Tsoukas CM, Bernard NF: Increased proportion of KIR3DS1 homozygotes in HIV-exposed 
uninfected individuals. AIDS 2008, 22:595-599, 510.1097/

QAD.1090b1013e3282f1056b1023.

67. Ravet S, Scott-Algara D, Bonnet E, Tran HK, Tran T, Nguyen N, Truong LX, Theodorou I, Barr/O-Sinoussi Fo, Pancino G, Paul P: Distinctive NK-cell receptor repertoires sustain high-level constitutive NK-cell activation in HIV-exposed uninfected individuals. Blood 2007, 109:4296-4305.

68. Guerini FR, Lo Caputo S, Gori A, Bandera A, Mazzotta F, Uglietti A, Zanzottera M, Maserati R, Clerici M: Under Representation of the Inhibitory KIR3DL1 Molecule and the KIR3DL1+/BW4+ Complex in HIV Exposed Seronegative Individuals. Journal of Infectious Diseases 2011, 203:1235-1239.

69. Boulet S, Kleyman M, Kim JYJ, Kamya P, Sharafi S, Simic N, Bruneau J, Routy J-P, Tsoukas CM, Bernard NF: A combined genotype of KIR3DL1 high expressing alleles and HLA-B*57 is associated with a reduced risk of HIV infection. AIDS 2008, 22:1487-1491, 1410.1097/ QAD.1480b1013e3282ffde1487e

70. Mallal S, Nolan D, Witt C, Masel G, Martin AM, Moore C, Sayer D, Castley A, Mamotte $C$, Maxwell D, et al: Association between presence of HLAB*5701, HLA-DR7, and HLA-DQ3 and hypersensitivity to HIV-1 reversetranscriptase inhibitor abacavir. The Lancet 2002, 359:727-732.

71. Smith MW, Dean M, Carrington M, Winkler C, Huttley GA, Lomb DA, Goedert JJ, O'Brien TR, Jacobson LP, Kaslow R, et al: Contrasting Genetic Influence of CCR2 and CCR5 Variants on HIV-1 Infection and Disease Progression. Science 1997, 277:959-965.

72. Hendrickson SL, Jacobson LP, Nelson GW, Phair JP, Lautenberger J, Johnson RC, Kingsley L, Margolick JB, Detels R, Goedert JJ, O'Brien SJ: Host Genetic Influences on Highly Active Antiretroviral Therapy Efficacy and AIDS-Free Survival. JAIDS Journal of Acquired Immune Deficiency Syndromes 2008, 48:263-271, 210.1097/QAl.1090b1013e31816fdc31815f.

73. Laurichesse JJ, Persoz A, Theodorou I, Rouzioux C, Delfraissy JF, Meyer L: Improved virological response to highly active antiretroviral therapy in HIV-1-infected patients carrying the CCR5 $\Delta 32$ deletion. HIV Medicine 2007, 8:213-219.

74. Marchetti G, Gori A, Casabianca A, Magnani M, Franzetti F, Clerici M, Perno CF, Monforte A, Galli M, Meroni L: Comparative analysis of T-cell turnover and homeostatic parameters in HIV-infected patients with discordant immune-virological responses to HAART. Aids 2006, 20:1727-1736.

75. Nemes E, Lugli E, Nasi M, Ferraresi R, Pinti M, Bugarini R, Borghi V, Prati F, Esposito R, Cossarizza A, Mussini C: Immunophenotype of HIV+ patients during CD4 cell-monitored treatment interruption: role of the IL-7/IL-7 receptor system. AIDS 2006, 20:2021-2032, 2010.1097/2001. aids.0000247575.0000241622.b0000247571.

\section{doi:10.1186/1479-5876-9-93}

Cite this article as: De Maria and Cossarizza: CD4saurus Rex

\&HIVelociraptor vs. development of clinically useful immunological markers: a Jurassic tale of frozen evolution. Journal of Translational Medicine 2011 9:93.

\section{Submit your next manuscript to BioMed Central and take full advantage of:}

- Convenient online submission

- Thorough peer review

- No space constraints or color figure charges

- Immediate publication on acceptance

- Inclusion in PubMed, CAS, Scopus and Google Scholar

- Research which is freely available for redistribution

Submit your manuscript at www.biomedcentral.com/submit
Biomed Central 